\title{
THE ROLE OF SPATIAL POLICY TOOLS PROTECTING THE SPACE AS A PUBLIC GOOD
}

\author{
Paweł MICKIEWICZ ${ }^{1 *}$, Maciej J. NOWAK ${ }^{2}$ \\ ${ }^{2}$ West Pomeranian University of Technology, Szczecin; pmickiewicz@zut.edu.pl, \\ ORCID: 0000-0003-1667-1290 \\ ${ }^{1}$ West Pomeranian University of Technology, Szczecin; maciej.nowak@zut.edu.pl, \\ ORCID: 0000-0001-6437-3226 \\ * Correspondence author
}

Purpose: The aim of the paper is to indicate functions that spatial policy tools at local level should fulfill while protecting the space understood as a public good.

Design/methodology/approach: The paper is of a review nature, but it refers to results of conducted research, included in the context of public goods.

Findings: The area of communes covered by local plans is varied and very often depends on random circumstances from the perspective of the main spatial policy framework. The above illustrates diverse conditions, in which spatial conflicts may occur. Factors that should theoretically play an ordering role actually bring much more chaos. Therefore, the behavior of communal authorities in the implementation of spatial policy is contained in the sphere of impacts difficult to clearly predict, about which E. Ostrom mentioned.

Social implications: In the context of current problems occurring in the spatial management system, it is worth developing the approach to space as a public good. This will help to adapt the approaches and characteristics of public goods to the current conditions of spatial management system and optimal role of spatial policy tools.

Originality/value: This paper defines the roles of spatial policy tools protecting the space understood as a public good. Space protection in this approach must be implemented through specific spatial policy tools. The paper verifies the real scope of such protection. An attempt was made to translate approaches and dilemmas regarding public goods into conditions related to the spatial management system.

Keywords: public goods, space, spatial order, planning and spatial development.

Category of the paper: General review. 


\section{Introduction}

Issues related to the protection of spatial order and proposing the optimal spatial management system can be undertaken from various perspectives. The perspective of institutional economics undoubtedly remains one of them. In the context of current problems occurring in the spatial management system, it is worth developing the approach to space as a public good. This will help to adapt the approaches and characteristics of public goods to the current conditions of spatial management system and optimal role of spatial policy tools. The aim of the paper is to indicate functions that spatial policy tools at local level should fulfill while protecting the space understood as a public good. Key issues have also been identified that should be addressed in this context. The paper is of a review nature, but it refers to results of conducted research, included in the context of public goods.

\section{Public goods}

A specific feature of the public good is that its unit can satisfy more than one consumer. Furthermore, an additional consumer does not reduce the amount of public good available to others. Thus, individual consumption of a good by one person does not exclude individual consumption of this good by others (Samuelson, 1954; 1958). The marginal cost of producing the public good is zero, and consumption of a public good is non-competitive. Hence, as pointed out (in the older, but still current context) by P. Samuelson, features of public goods are:

- no exclusion (of anyone from consuming or benefiting from the good once delivered),

- indivisibility,

- no competition (i.e. simultaneous use of a given good by all market participants).

A. Kargol-Wasiluk links the occurrence of public goods with the occurrence of collective needs. Examples include national defense, public safety, sanitary protection, street lighting, and the use of public roads. The recipient is the whole society (Kargol-Wasiluk, 2008), or rather defined - a local, regional or national community. The following features of public goods can be distinguished:

- should bring divisible benefits,

- should be the subject of total consumption,

- their consumption should be equal,

- equality with this consumption cannot be differentiated based on whether or not the consumer wants to pay for the good,

- supply of consumer goods cannot be rationed in any way,

- consumption of public good cannot be competitive (Fiedor, 2002). 
A. Surdej distinguishes between competitive goods in consumption (private goods and goods for shared use) and non-competitive goods in consumption (club goods and pure public goods). Excluding from consumption is a separate element (private and club goods are excluded). The author indicates that the criteria of consumption non-competitiveness and non-exclusion from consumption are met by small number of goods - pure public goods (Surdej, 2006). In this context, it seems appropriate to stipulate that there are very few public goods in a real model approach. Criteria listed above for "pure public goods" are hardly ever fully met. In practice, it is primarily possible to find mixed goods: possessing the characteristics of private and public goods, including, for example, goods of a much larger number of characteristics of public goods than private ones. It can also be seen that different features of specific goods in different markets and in different situations may look different. One of the key elements should be to verify the actual degree of their exclusion.

According to another approach, four types of goods can be distinguished:

- private, that are characterized by total exclusivity and individual consumption,

- for a fee - exclusivity and collective consumption (e.g. housing, food, car, private apartment),

- joint - non-exclusive and individual consumption (e.g. city parks),

- team - non-exclusivity and collective consumption (e.g. security in cities).

According to W. Gaczek, all goods, except private goods, can be roughly treated as public goods. It is the authorities (central, regional, local), who determine how much public funds will be allocated to public goods (Gaczek, 2003). Thus, the authorities shape these goods. This approach can be largely agreed, especially in the context of special treatment of public goods themselves; first of all, due to the fact that in practice there are no public goods that fully meet all textbook attributes assigned to them. It should also be noted that, according to E. Ostrom, with every institutional solution aimed at regulating access to goods that are jointly owned in a way that achieves multiple purposes, this requires prior answers, among others, to the following questions:

- who will be authorized to exploit what kind of resource?

- who will supervise the exploitation of resources?

- what sanctions threaten for failing to comply with the rules?

- how will potential conflicts be resolved?

- how is the issue of multidimensional links between different levels of action to be solved?

- how is the unforeseen accident to be resolved?

- how will the rules set out over time change in response to ongoing internal and external changes (Ostrom 2012; 2005)?

These issues will be used in the context of the protection of space understood as a public good. 


\section{Space as a public good}

R. Stiglitz points out that one of the most important public goods is the quality of state management. The model-managed state has the characteristics of public goods in this approach. They rely on the fact that excluding anyone from the benefits of a better state is difficult and undesirable. The above manifestation is the increase in the state's efficiency of operations and reduction of taxes without limiting the scope of public services provided (Stiglitz, 2004). The above principle can also be applied to issues related to spatial planning. The initial assumption would be that the external effect is the quality of space management and:

- guaranteeing such solutions that will sufficiently protect spatial order and related environmental and natural conditions,

- guaranteeing efficiency and transparency at the local level by creating clear, objective and transparent spatial development criteria.

Therefore, public interests related to spatial management are inseparably connected with the category of public goods. They are understood as all products of human activity of every citizen's interest, to which access on equal terms is guaranteed by public authorities of all levels in accordance with their real competences and possibilities of the economy (Markowski, Drzazga, 2015). In other words, it can be stated that public goods are:

- space shaped according to the spatial order,

- access to environmental and natural values of space,

- clarity regarding the rights of individual entities in the field of spatial development,

- related opportunity to the implementation of projects important from the perspective of individual investors (Nowak, 2017).

Given the above, it is necessary to verify the framework of institutional regulation of access to space understood as public goods. In this context, the basis for further considerations will be an attempt to answer the questions (after prior adjustment) proposed by E. Ostrom and transfer them to the optimal spatial management system. As a rule, every participant in a given community should have an access to a common space, including the environmental, cultural and composition-aesthetic values associated with it. The access cannot be unrestricted one should also take into account the framework related to the right of property owners. However, the limit for the latter is protection of values related to spatial order. In detail, this boundary will be clarified through spatial policy tools. And it is within these tools (prepared by the public authority) that the framework for supervision over the exploitation of space will also be included. In this respect, first of all, administrative sanctions (e.g. demolition order, fees) can be attributed for non-compliance with adopted rules, but not criminal sanctions. Solving the potential spatial conflicts is actually a wider, problematic issue. Even the most precise possible definition of the principles in the tools of spatial policy will not lead to the complete elimination of these conflicts. And in this context, the unforeseen accidents pointed out by E. Ostrom must be cited. The range of possible spatial conflicts, but also the subject of these 
conflicts, can be very wide. In addition to typical conflicts (also highlighted in the literature on the subject), e.g. between an economic investor and residents of a given area, there may also be other (including "apparent spatial conflicts"), as well as standard conflicts, in which participants of the game for space derive non-standard arguments and works. From the perspective of protecting the space as a public good, the direction that occurs in Poland, according to which in such situations, in principle, acts are in favor of individual owners/investors, is questionable. However, it is not possible to propose an ideal scheme that provides a full basis for resolving the unforeseen situations. Risk is an inseparable element of the spatial management system.

In the analyzed context, the question posed by E. Ostrom seems to be very adequate in order to solve the issue of multidimensional connections between different levels of activity. In the context of an access to space, this can be multidirectional:

- from the perspective of the level and subject of interference in the space (e.g. scope of the investment being implemented),

- from the perspective of the category of interference in space (e.g. interference related to wider buildings, interference related to guaranteeing protection to a certain extent).

While the arrangement of spatial policy tools, when implementing institutions associated with public management, allows a broader organization of the level of interference, there will be a problem mutually differentiated within most categories of terminology (e.g. there is a significant discrepancy between planning and environmental terminology) with multidimensional interrelationships related to the category of interference. Arranging the multidimensional relationships is therefore still a significant research challenge to a significant extent. The same challenge is to modify the established rules as internal and external changes occur. One can cite here the postulate of integrated development planning, which - adapted to the spatial management system - would also at least significantly reflect these changes by nature.

In conclusion, it can be pointed out that the following key challenges in the analyzed context remain:

- defining precise rules for the scope and protection of space in spatial policy tools,

- creation a mechanism for resolving spatial conflicts in the spatial policy tools taking into account possible differentiated multidimensional connections as well as changes and impacts taking place.

\section{Functions of spatial policy tools}

As part of these considerations, reference was made to two key spatial policy tools at the local level, i.e. studies of spatial development conditions and directions, as well as local spatial development plans. The analysis should, however, be started from the basic framework, 
possibilities and limitations of local spatial policy. W. Gaczek, among features of the active way of conducting spatial policy mentions, among others:

- emphasis on implementing the agreed spatial policy objectives,

- searching for efficient and effective implementation instruments,

- cost analysis of achieving goals and securing financial resources,

- using the strategic approach in achieving the adopted spatial development goals and linking action programs with them,

- use of an extensive set of diverse instruments (e.g. urban and architectural, legal, economic and financial, or marketing),

- use of market land management instruments ensuring funds for achieving the commune's goals,

- taking preventive actions that do not allow restrictions on the development of the commune,

- taking active measures to combine various external sources of financing in the implementation of spatial development programs (Gaczek, 2003).

Among the main problems, T. Markowski includes:

- introducing optional local planning,

- basing the issuing of location decisions on pathological and corruption-generating principles,

- defective provisions of laws regarding financial settlements in spatial planning,

- expansion of the special laws,

- ease of appealing against planning decisions and case law chaos,

- low flexibility of spatial planning,

- strengthening the traditional approach to spatial planning at supra-communal levels,

- orientation of local governments only towards internal matters and excessive intergovernmental competition,

- information barriers,

- low level of human capital (Markowski, 2011).

There is no doubt, therefore, that there is a serious gap between the goals and expectations of spatial policy and real possibilities. This should also be taken into account when assessing the function of the study and local plans (Bąkowski, 2018; Śleszyński, Stępniak, Mazurek 2018; Zawadzka, 2017). The assumption of creating the current spatial management system was that the study of conditions and directions of spatial development is to constitute a basic spatial document in the commune. J.M. Chmielewski emphasizes that the study by means of specific principles can define the future desired spatial structure without falling within the impassable framework for freedom of planning local (Chmielewski, 2010). It can be concluded that the study is primarily a comprehensive collection of information on: 
- existing spatial conditions (in other words, related to shaping the spatial order) of the commune,

- planned directions in the area of undertaken activities.

In accordance with the assumptions underlying the spatial management system in Poland, a key document at the local level should be local spatial development plans (Mickiewicz, Nowak, 2019; Nowak, 2015; Kowalewski, 2019; Izdebski et al., 2018). M. Feltynowski even indicates that the adoption of local plans significantly determines the effectiveness of spatial policy in the commune (Feltynowski, 2009). Their most important role can be reduced to the following elements:

- determination of land use,

- delimiting the areas for various purposes,

- defining a building ban for specific plots,

- defining the rules related to environmental and nature protection.

Theoretically, the above arrangement should guarantee the first challenge outlined in the previous section, i.e. definition of precise rules related to the space development. In practice, however, this system is blocked by the following factors:

- lack of wider use of some spatial policy tools, in particular local spatial development plans,

- local plans adopted do not consistently protect the values of areas related to spatial order (which is caused primarily by the fears of municipal authorities against compensation claims of property owners).

The scale of the problem is illustrated by results of the research. As part of the author's previous publication, spatial policy in 299 communes (from voivodeships throughout Poland) was analyzed, including the use of spatial policy tools.

Table 1.

Application of spatial policy tools in selected communes

\begin{tabular}{|l|l|l|}
\hline $\begin{array}{l}\text { Area of communes covered } \\
\text { by local plans }(\%)\end{array}$ & $\begin{array}{l}\text { Number of communes meeting } \\
\text { the criteria related to the area } \\
\text { covered by the plans }\end{array}$ & $\begin{array}{l}\text { Percentage share of communes in } \\
\text { which building conditions are not } \\
\text { denied at all - in a given group }\end{array}$ \\
\hline 0 & 26 & 57,6 \\
\hline $0,1-20$ & 117 & 25,6 \\
\hline $20-50$ & 25 & 24 \\
\hline More than 50 & 121 & 39,7 \\
\hline
\end{tabular}

Source: own study based on (Nowak, 2017).

In Table 1, attention was paid to the planning coverage of communes and issuing decisions on building conditions dependent on that coverage (a tool replacing the local spatial development plan in the absence of it in a given area). In the whole country, slightly more than $30 \%$ of the area is covered by local spatial development plans. The results contained in Table 1 show that the area of communes covered by local plans is varied and very often depends on random circumstances from the perspective of the main spatial policy framework. 
It is rare that the local plan covers a space recognized as e.g. the most important public good in a given commune (from this perspective). Rather, local plans cover areas designated for specific buildings - thus, it is primarily about meeting the individual needs of individual space users. A broader tendency to order the space can be found only in the communes covered by local plans in the scope exceeding 50\%. However - as confirmed by results from Table 1 - also in these communes in other areas (not covered by local plans), communal authorities are virtually uncritical in relation to the submitted applications for determining the development conditions, allowing virtually all submitted concepts. Provided that the communal authorities are bound by specific requirements in such proceedings, it must be stated that such a large scale of communes, taking into account all applications, undoubtedly translates into consequences in the form of limiting the value of space, also in its above-mentioned understanding as a public good.

The above illustrates diverse conditions, in which spatial conflicts may occur. Factors that should theoretically play an ordering role actually bring much more chaos. Therefore, the behavior of communal authorities in the implementation of spatial policy is contained in the sphere of impacts difficult to clearly predict, about which E. Ostrom mentioned.

Repairing the indicated problems should be as follows:

- creating a broader system basis for adopting the local spatial development plans (or their equivalents), while consistently maintaining, for example, tendency analysis related to the protection of space values that can be associated with recognizing them as public goods,

- integrating development planning, also (or rather above all) in the spatial dimension in addition to achieving other goals, this will allow for a broader view of space in the context of public goods.

\section{Conclusions}

Specific actions taken by communal authorities and space users have a dimension directly related to the economic context. Failure in considering this context will lead to significant losses in the long term. This is fully inscribed in the context of the problems undertaken, among others, in publications by E. Ostrom. And it is her proposed focus on the analysis of issues related to public goods that finds full application in the spatial management system. 


\section{References}

1. Bąkowski, T. (2018). Prawne problemy rozpraszania i koncentracji zabudowy. Gdańsk: Wydawnictwo Uniwersytetu Gdańskiego, 13-20.

2. Chmielewski, J.M. (2010). Współzależność ustaleń studium uwarunkowań i kierunków zagospodarowania przestrzennego i miejscowych planów zagospodarowania przestrzennego. In: J.M. Chmielewski, G. Węcławowicz, Studium uwarunkowań $i$ kierunków zagospodarowania przestrzennego a miejscowe plany zagospodarowania przestrzennego. Biuletyn Komitetu Przestrzennego Zagospodarowania Kraju PAN, 245. Warszawa: KPZK PAN, 12.

3. Feltynowski, M. (2009). Polityka przestrzenna obszarów wiejskich. W kierunku wielofunkcyjnego rozwoju. Warszawa: CeDeWu, 42-43.

4. Fiedor, B. (2002). Podstawy ekonomii środowiska i zasobów naturalnych. Warszawa: Beck, 40-52.

5. Gaczek, W. (2003). Zarzadzanie w gospodarce przestrzennej. Bydgoszcz-Poznań: Branta, 15.

6. Izdebski, W., Śleszyński, P., Malinowski, Z., Kursa, M. (2018). Analiza morfometryczna planów miejscowych w Polsce. Infrastruktura i ekologia terenów wiejskich, N II. Kraków: Commission of Technical Rural Infrastrukture, 331-340.

7. Kargol-Wasiluk, A. (2008). Teoria dóbr publicznych a paradygmat ekonomii sektora publicznego. Zarzadzanie publiczne, 3. Warszawa: Wydawnictwo Naukowe Scholar, 92.

8. Kowalewski, A. (2019). Interes publiczny i przestrzeń - kilka uwag. In: J. Danielewicz, D. Sikora-Fernandez (eds.), Zarządzanie rozwojem współczesnych miast. Łódź: Uniwersytet Łódzki, 265-270.

9. Markowski, T. (2011). Funkcjonowanie gospodarki przestrzennej - założenia budowy modelu zintegrowanego planowania i zarządzania rozwojem. In: T. Markowski, P. Żuber (eds.), System planowania przestrzennego i jego rola $w$ strategicznym zarzadzaniu rozwojem kraju. Studia KPZK PAN, CXXXIV. Warszawa, 26, 27, 37-39.

10. Mickiewicz, P., Nowak, M.J. (2019). The impact of nature conservation types on the house investments development. Economic Science for Rural Development Conference Proceedings.

11. Nowak, M. (2015). Nieefektywność decyzji o warunkach zabudowy i zagospodarowania terenu w kształtowaniu ładu przestrzennego a działania organów administracji publicznej. In: J. Martyniuk-Pęczek, M. Nowak (eds.), Aktualne problemy zarzadzania rozwojem przestrzennym w Polsce. Biuletyn KPZK PAN, 257.258. Warszawa, 46.

12. Nowak, M. (2017). Niesprawność władz publicznych a system gospodarki przestrzennej. Studia KPZK PAN. WarszawaŁ Wydawnictwo Polskiej Akademii Nauk, 45-53. 
13. Ostrom, E. (2005). Understanding Institutional Diversity. Princeton: Princeton University Press, http://press.princeton.edu/titles/8085.html, 25.10.2019.

14. Ostrom, E. (2012). Instytucje i środowisko. Zarzadzanie publiczne, 2. Warszawa: Wydawnictwo Naukowe Scholar, 95.

15. Samuelson, P.A. (1954). The Pure Theory of Public Finance, expenditures. Review of Economics and Statistics, 36(4), 387-389.

16. Samuelson, P.A. (1958). Aspects of public Expenditure Theories. Review of Economics and Statistics, 40(4), 332.

17. Stiglitz, J. (2004). Ekonomia sektora publicznego. Warszawa: PWN, 176-177.

18. Surdej, A. (2006). Determinanty regulacji administracyjnoprawnych $w$ oddziatywaniu państwa na gospodarkę. Kraków: Wydawnictwo Akademii Ekonomicznej, 161-164.

19. Śleszyński, P., Stępniak, M., Mazurek, D. (2018). Oszacowanie skutków presji inwestycyjnej i nadpodaży gruntów budowlanych w strefie podmiejskiej Warszawy na przykładzie gmin pasma zachodniego. Przeglad Geograficzny, 2. Warszawa: Instytut Geografii i Przestrzennego Zagospodarowania, 233-234.

20. Zawadzka, A. (2017). Ład nasz przestrzenny. Gdańsk-Warszawa: Wolters Kluwer, 44. 